\title{
ПОНЯТТЯ СУДОВОї ДИСКРЕЦІї ЯК ЕЛЕМЕНТА ПРАВОЗАСТОСУВАННЯ СУДУ: ТЕОРЕТИКО- ПРАВОВИЙ АСПЕКТ
}

\author{
КЛЮЧКОВИЧ Василь Юрійович - аспірант Дніпропетровського \\ державного університету внутрішніх справ \\ DOI:10.32782/LAW.2019.3.4 \\ УДК 340.11: 347.92 (045)
}

В статье рассмотрено проблематику судебной дискрещии (усмотрения) как элемента правоприменения суда с позиций науки теории государства и права. Вълделенъ научнъие подходъг к пониманию термина «усмотрения органов публичной власти». Предложено авторское определение термина «судебная дискреция».

Ключевые слова: дискреция, судебное усмотрение, дискречионнве полномочия, правовое государство, органъ судебной власти, гражданское общество.

у сучасних умовах державно-правової та суспільної трансформації, коли суб'єкти публічної влади та громадянського суспільства системно здійснюють пошук та модернізують шляхи їх взаємодії, провідне значення відіграє прийняття суспільно корисних та важливих рішень органами державної влади й особливо органами судової влади. Адже незалежна та самостійна судова влада виступає запорукою досягнення основної мети суспільства - забезпечення прав і свобод людини і громадянина. До того ж, це і $є$ головним критерієм визначення рівня демократичності тієї чи іншої держави.

Підвищення ефективності та ролі органів судової влади у належному функціонуванні суспільства у цілому та окремих його суб'єктів, зокрема, прямо взаємозалежне 3 якістю судових рішень. Неможливість й, головне, недоречність, всецілого прописування у нормативно-правових актах поведінки суб'єктів права у різних життевих ситуаціях вирішується шляхом прийняття рішень на власний розсуд різними суб'єктами влади, зокрема суддівським корпусом, реалізуючи таким чином дискреційні повноваження, передбачені законодавством. Тож забезпечення функціонування органів судової влади на високоефективному рівні вимагає вирішення у багатьох напрямах, серед яких визначення сутності та змісту судової дискреції (розсуду).

Поняття розсуду є одним із провідних у науці теорії держави і права та у галузевих юридичних науках. Онтологічні, функціональні, телеологічні, правові та інші аспекти дискреції суб'єктів публічної влади, у тому числі судової, з позицій різних наукових шкіл та напрямів у межах $\phi і-$ лософії, соціології, психології, політології, юриспруденції вивчали такі науковці, як Д. Абушенко, С. Алексєєв, Ф. Аллен, В. Антропов, В. Бабаєв, А. Барак, В. Баранов, ᄉ. Берг, О. Боннер, Г. Бребан, Е. Васьковський, Н. Вопленко, М. Гарієвська, Ю. Грачова, А. Грінь, Р. Дворкін, К. Девіс, М. Зейдер, В. Канцір, А. Коренєв, В. Коцкулич, В. Аемак, Д. Ауспеник, Т. Мартьянова, Ф. Нонет, О. Папкова, О. Петришин, В. Ремньов, Ч. Рейч, М. Рісний, О. Семеній, О. Сеньків, О. Скакун, Ю. Тихомиров, М. Треушніков, Н. Ханова, О. Черданцев, Н. Чечіна, Д. Чечот, В. Ямковий та ін. Проте історико-джерелознавчий аналіз та сучасна судова практика свідчать, що пи- 
тання судового розсуду вимагає подальшого ретельного комплексного вивчення у межах загальної теорії держави і права як науки інтегруючої, універсальної та узагальнюючої, здатної знайти відповіді на головні питання юриспруденції й таким чином вирішити низку практичних правознавчих завдань.

Поява судового розсуду як правового явища сягає давніх часів та пропорційно пов'язана 3 виникненням інституту суду. Незважаючи на нормативне закріплення і вживання терміна «судова дискреція» («судовий розсуд») в літературі вже досить тривалий час, неодноразове його згадування та тлумачення у рішеннях різних інстанцій судової влади, зміст цього терміна залишається суперечливим, дискусійним та потребує подальшої наукової розробки, адже відсутність єдності в його розумінні унеможливлює якісний процес правозастосування органами судової влади.

У доктринальних джерелах та нормативно-правових актах використовуються такі категорії, як «розсуд» та «дискреція», а також діалектично взаємопов’ язані з ними «дискреційна влада», «дискреційні повноваження», «дискреційні рішення» тощо. Аналіз наукових джерел щодо співвідношення категорій «дискреція» та «розсуд» свідчить про визнання вченими їх тотожними, проте автори все ж пропонують певні уточнення, на що й слід звернути увагу.

В енциклопедичних джерелах розсуд трактують як: 1) рішення, висновок; 2) розмірковування, роздум [1, с. 819]; згідно $з$ рішенням, позиція, думка кого-небудь [2] тощо.

У свою чергу, «дискреція» у перекладі $з$ англійської «discretion»- це здоровий глузд або ж свобода розсуду [3, с. 50]. Вважаємо, що такі компоненти, як «здоровий глузд» або ж «свобода розсуду» у разі реалізації дискреції органів влади не можуть бути взаємозамінними, а лише виступати як обов’ язкові складові єдиного цілого.

3 французької «discretionnarie» означає той, що залежить від власного розсуду [4, с. 180]. Звісно, що такий підхід є узагальненим, і якщо екстраполювати його на юридичну сферу, то неодмінним елементом висту- пить також залежність посадової особи від чинного законодавства.

3 латинської «discretio», німецької «discretion», польської «dyskrecyja» - воля, розсуд, розпорядження [5]; рішення посадової особи або державного органу віднесеного до їх компетенції питання на власний розсуд в порядку реалізації дискреційної влади [6]. Отже, розгляд етимологічного походження категорій «дискреція» та «розсуд» свідчить про їх рівноцінне змістовне значення.

Проте, на думку Н. Ханової, у загальнотеоретичному розумінні терміни “розсуд» $\mathrm{i}$ «дискреція» $є$ тотожними за своїм змістом. 3 одного боку, за своїм змістовним наповненням вони й дійсно $є$ тотожними, а 3 другого - все ж таки мають деякі формальні відмінності. Так, якщо йдеться про дискрецію, вона стосується виключно реалізації розсуду суб'єктом владних повноважень; вона не застосовується суб'єктом, який не наділений такими повноваженнями.У свою чергу, оперування терміном «розсуд» $\epsilon$ можливим як щодо владного суб'єкта, так і щодо зобов' язаного учасника податкових відносин (дискреиійні повноваження контролюючих органів у сбері оподаткування є предметом авторсъкого дослідження - В.Ю.) [7, с. 59-61]. Тобто «розсуд» та «дискреція» 6 змістовно тотожними явищами, проте, якщо мова йде про розсуд, то цей термін доречно застосовувати як щодо державних, так і недержавних суб'єктів, термін “дискреція» доцільно вживати лише по відношенню до суб'єктів публічної влади. Можливо, такий підхід і потребує подальшого вивчення, проте у контексті нашого дослідження вказані категорії будуть використовувати як змістовно рівнозначні явища, адже досліджуватиметься розсуд органів державної влади, зокрема суду.

Переходячи до авторських інтерпретацій розсуду (дискреції), акцентуємо першочергово, що розсуд - невід'ємний елемент правозастосовної діяльності, об'єктивно існуюче і соціально виправдане правове явище, в якому виражається динамізм права, його пристосованість до постійно змінюваних історичних умов і конкретних ситуацій [8, сс. 7-8, 18-19]. Дослідження зарубіж- 


\section{Теорія, історія держави і права, конституційне право}

ної та вітчизняної наукової доктрини щодо розуміння розсуду органів публічної влади надає підстави для виокремлення декількох підходів у цьому напрямі: 1) розсуд (дискреція) як міра свободи; 2) розсуд (дискреція) - окремий вид діяльності; 3) розсуд (дискреція) - спосіб прийняття рішення безвідносно до волі інших суб'єктів; 4) розсуд (дискреція) як повноваження, що передбачене законодавством та ін.

Так, О. Коренєв пояснюе розглядуване поняття як установлену нормативними рамками міру свободи органу державної влади при вирішенні конкретної індивідуальної справи, що надається останньому 3 метою забезпечення прийняття найбільш оптимального рішення [9, с. 34]. Акцентує увагу на досягненні нормативно-детермінованої мети шляхом реалізації розсуду Р. Краутхаузен, який розуміє під цим явищем свободу органів державної влади діяти в межах, чітко встановлених законом [10, с. 133]. Наведені визначення є дещо обмеженими, адже автори зазначають лише нормативний аспект як стримуючий чинник під час прийняття дискреційного рішення посадовою особою.

А. Барак вважає, що розсуд слід розуміти як повноваження, яке надається владному суб'єкту і яке полягає у можливості вибору між двома або ж більше альтернативними алгоритмами поведінки, коли будь-який 3 них є законним [11, с. 187]. К. Девіс також акцентує увагу на алгоритмі поведінки, який треба обрати: можливість посадової особи органу державної влади діяти на підставі свободи обрання конкретного алгоритму поведінки 3-поміж низки можливих дій або ж бездіяльності [12, с. 167]. Такий підхід, безперечно, заслуговує на увагу, проте говорити про алгоритм поведінки в умовах недосконалого законодавства видається у багатьох випадках майже неможливо.

На думку Ю. Тихомирова, під розсудом треба розуміти можливість владного суб'єкта зробити мотивований вибір при прийнятті конкретного рішення чи здійсненні дій 3 метою виконання поставлених, нормативно-детермінованих завдань [13, с. 74]. На переконання Т. Мартьяно- вої, доцільним є вживання у поняттєво-категорійному апараті загальної теорії держави і права терміна «розсуд суб'єктів правозастосовної діяльності» - це передбачене нормами права владне повноваження, зміст якого полягає в можливості суб'єкта правозастосовної діяльності в межах своєї компетенції здійснювати мотивований вибір варіантів дії під час вирішення спірного правового питання, шляхом ухвалення правомірного рішення, враховуючи принципи права, положення чинного законодавства, конкретні обставини справи, а також вимоги доцільності, добросовісності, справедливості та основи моралі [14, с. 12-13]. Таким чином, авторка розглядає більш широко це явище, виходячи за рамки нормативно-правового регулювання дискреції й акцентує увагу не лише на правовій природі правозастосовного розсуду, а й на моральній.

О. Папкова наголошує, що під розсудом потрібно розуміти регламентований нормативними положеннями й реалізовуваний у процесуальній (процедурній) формі різновид діяльності, яка змістовно полягає у наданні органові державної влади повноважень щодо самостійного вирішення спірних питань з урахуванням об'єктивних обставин справи, спираючись на цілі та принципи відповідно до критеріїв справедливості, розумності й загальновизнаних засад моралі [15, с. 207]. Слід зауважити, що науковець наголошує на самостійності вирішення питання тим чи іншим органом державної влади (деякі інші автори також наголошують на цьому аспекті), проте, на нашу думку, він не є цілком коректним, адже будь-який орган державної влади зобов'язаний самостійно приймати рішення 3 того чи іншого питання, що входить в рамки його компетенції, без втручання в його діяльність інших осіб. Тим більше, коли мова йде про судову владу.

I. Поляков розглядає розсуд як акт вибору органом державної влади конкретної мети й, відповідно, способу ії досягнення, як прийняття цим органом рішення безвідносно до волі інших суб'єктів [16, с. 235]. Вважаємо, що таке визначення потребує певного уточнення, зокрема, щодо вибору 
органом державної влади конкретної мети. Мета встановлюється законодавцем, інші органи державної влади мають реалізувати цю мету за допомогою різних законних способів.

Отже, проведений аналіз різних позицій щодо розуміння розсуду (дискреції) органів влади надав можливість розкрити особливості та виділити окремі підходи до розуміння цього явища. Наголосимо, що виокремленням підходів до розуміння розсуду є умовним й має виключно теоретичне значення, проте сприятиме максимально коректному формулюванню розсуду у подальшому, що вже буде мати теоретико-прикладне значення. Переходячи від загального до конкретного, тобто від аналізу терміна “розсуд» до з'ясування змісту терміна «судовий розсуд», що власне і виступає предметом дослідження, зазначимо, що в основу наведених нижче та взагалі існуючих визначень судового розсуду покладено формулювання розсуду влади, проте 3 відображенням відповідної специфіки.

Так, судовий розсуд автори розглядають крізь призму свободи. Д. Абушенко наголошує, що філософсько-правовою основою судового розсуду є свобода у діяльності правозастосовного органу (свобода розуміється як право вибору одного із передбачених законодавцем варіантів) [17]. На думку О. Стьопіна, судовий розсуд - це представлене судді законом повноваження свободи вибору одного з декількох закріплених у правовій нормі альтернативних, але в рівній мірі законних рішень у справі [18, с. 23-24]. Вважаємо, що таке визначення потребує уточнення, адже у запропонованому формулюванні очевидно не вистачає, зокрема, «виборі мотивованого рішення», «3 урахуванням обставин справи» тощо.

ᄉ. Берг тлумачить судовий розсуд як елемент судової правозастосовної діяльності, що полягає у виборі мотивованого законного і обгрунтованого рішення, що здійснюється уповноваженим суб'єктом (суддею) по конкретній юридичній справі у межах, встановлених нормою права [19]. О. Боннер вважає, що під судовим розсудом потрібно розуміти надані суду повно- важення вирішувати правові питання 3 урахуванням обставин справи, загальних положень закону, принципів права, економічних законів розвитку суспільства й норм моралі [20, с. 56]. Позитивно, що автор згадує про моральний аспект судового розсуду.

П. Марков наголошує, що судовий розсуд становить не особливі повноваження, надані суду, а спосіб здійснення владних повноважень щодо вирішення правових суперечок і вчинення окремих процесуальних дій. Судовий розсуд - це вільна діяльність суду по вирішенню конкретної справи у цілому або здійснення окремої процесуальної дії відповідно до особистих переконань судді, яка полягає у виборі одного з декількох варіантів вирішення спору, передбачених формальними джерелами права, або спрямована на подолання колізій та прогалин у позитивному регулюванні і має результатом (метою) формування правового рішення [21, с. 7-8]. Також підтримуємо позицію автора $з$ приводу того, що в межах дискреції «суд має обирати між двома та більше варіантами вирішення справи» є помилковими, оскільки існують випадки, коли питання, що потребує правового вирішення, раніше ніколи ще не розглядалося або запропоноване раніше рішення має неправовий характер.

Оскільки реалізацію розсуду теоретики та практики логічно пов'язують 3 виконанням дискреційних повноважень, то окремим дискусійним питанням у правовій науці нині виступає поняття «дискреційні повноваження».

Зауважимо, що фактичної одностайності серед науковців досягло положення про те, що повноваження - це певні права й обов'язки діяти, вирішуючи коло справ, визначених компетенцією [22]. Тобто складовими повноважень будь-яких органів влади є права та обов'язки.

У контексті розуміння терміна «повноваження» більш доцільно вести мову про те, що розсуд пов'язаний саме 3 таким їх складником, як права органу державної влади, наголошує С. Резанов [23, с. 181-182].I справді, у літературі, наприклад, зазначається, що дискреційні повноваження - це 


\section{Теорія, історія держави і права, конституційне право}

право глави держави, голови уряду, інших посадових осіб органів державної влади діяти за певних умов на власний розсуд у межах закону [6].

Важливо, що категорія «дискреційні повноваження» отримала свою формалізацію на національному та на європейському рівні.

У Рекомендації Комітету міністрів Ради Європи № R(80)2, що стосується здійснення адміністративними органами влади дискреційних повноважень від 11 березня 1980 р., дискреційні повноваження (discretionary power) - повноваження, які адміністративний орган, приймаючи рішення, може здійснювати 3 певною свободою розсуду, тобто, коли такий орган може обирати 3 кількох юридично допустимих рішень те, яке він вважає найкращим за даних обставин [24; 25]. Із запропонованого визначення, на жаль, не вдається чітко встановити, що саме розуміється під повноваженнями.

На національному рівні визначення терміна «дискреційні повноваження» сформульовано у Методології проведення антикорупційної експертизи: це сукупність прав та обов'язків органів державної влади та місцевого самоврядування, осіб, уповноважених на виконання функцій держави або місцевого самоврядування, що надають можливість на власний розсуд визначити повністю або частково вид і зміст управлінського рішення, яке приймається, або можливість вибору на власний розсуд одного 3 декількох варіантів управлінських рішень, передбачених нормативно-правовим актом, проектом нормативно-правового акта [26]. Отже, у запропонованому тлумаченні терміна “дискреційні повноваження» прямо йдеться про права та обов'язки. Однак, як уже було наголошено, не всі науковці погоджуються з таким розумінням дискреційних повноважень.

Так, коментар до наведеного визначення висловив М. Самбор. На його думку, виконання обов'язків за своїм змістом не може належати до адміністративного розсуду, адже обов'язок сам по собі є вимогою до виконання, а не можливістю виконання, тоді як адміністративний розсуд пропонує альтернативу, дозволяє як виконувати, так і утриматися від виконання певних дій, прийняття рішень в одних і тих самих умовах. Тому адміністративним розсудом можуть і повинні бути охоплені виключно права суб'єктів владних повноважень, що за своєю юридичною природою є можливостями, які використовуються за власним розсудом їх носія для задоволення його інтересу (професійного інтересу), а точніше - інтересу органу влади [27, с. 33].

Аналогічний підхід висловив також А. Старик: терміносполука «дискреційні повноваження» містить у собі логічну помилку, оскільки реалізація дискреції 6 правом суб'єкта, але вона ніяк не стосується другого складника поняття «повноваження» - обов'язків. Тому, напевно, було б більш доцільніше говорити про поняття «дискреційні права», а не про «дискреційні повноваження» або ж якимось чином окреслити умовність використання терміна «повноваження» у цій конструкції [28, с. 110].

Інша група науковців та практиків стверджує, що дискреційні повноваження все ж включають права та обов'язки. Дискреційні повноваження - це комплекс прав і зобов'язань представників влади як на державному рівні, так і на регіональному, у тому числі представників суспільства, яких уповноважили діяти від імені держави чи будь-якого органу місцевого самоврядування, що мають можливість надати повного або часткового визначення i змісту, і виду прийнятого управлінського рішення [29]. В. Ямковий вважає, що дискреційні повноваження $\varepsilon$ сукупністю прав та обов'язків, закріплених у встановленому законодавством порядку за судом, які він застосовує на власний розсуд [30, с. 170].

Високо оцінюючи всі наукові досягнення у досліджуваному напрямі, вважаємо за доцільне особливу увагу звернути на позицію Верховного Суду: поняття судової дискреції (судового розсуду) у кримінальному судочинстві охоплює повноваження суду (права та обов'язки), надані йому державою, обирати між альтернативами, кожна 3 яких 6 законною, та інтелектуально-вольову владну діяльність суду з вирішення у визначених законом випадках спірних 
правових питань, виходячи із цілей та принципів права, загальних засад судочинства, конкретних обставин справи, даних про особу винного, справедливості й достатності обраного покарання тощо [31]. Таким чином, суд виходить з того, що дискреційні повноваження включають як права, так і обов'язки.

Удосконалення правового регулювання діяльності судової влади, зокрема суддівського розсуду, неможливо без поглибленого загальноправового аналізу процесів, які відбуваються у суспільстві. Правове регулювання дискреції суду має будуватися з урахуванням досягнень вітчизняної та зарубіжної науки теорії права; грунтуватися на застосуванні положень і принципів норм моралі та культури суспільства.

Підводячи підсумки, наголосимо, що у науці фактично відсутні теоретико-правові дослідження, присвячені комплексному аналізу правового та морального аспектів дискреції суддів.

1. Поява судового розсуду як правового явища сягає давніх часів та пропорційно пов'язана з виникненням інституту суду. У доктринальних джерелах та нормативно-правових актах використовуються такі категорії, як «розсуд» та «дискреція», а також діалектично взаємопов’язані $з$ ними «дискреційна влада», "дискреційні повноваження», «дискреційні рішення» тощо. Аналіз енциклопедичних та наукових джерел щодо співвідношення категорій «дискреція» та «розсуд» органами публічної влади свідчить про їх тотожність.

2. Категорія «дискреція» («розсуд») стикається 3 різними складовими правової реальності (правотворчість, правозастосування тощо) та все частіше використовується в юридичній доктрині та нормативно-правовій базі. Питання дискреції має провідне значення у практиці суб'єктів застосування норм права. Дослідження зарубіжної та вітчизняної наукової доктрини щодо розуміння розсуду органів публічної влади надало підстави для виокремлення таких підходів у цьому напрямі: 1) розсуд (дискреція) як міра свободи; 2) розсуд (дискреція) - окремий вид діяльності; 3) розсуд (дискреція) - спосіб прийняття рішен- ня безвідносно до волі інших суб'єктів;4) розсуд (дискреція) як повноваження, передбачене законодавством та ін. Виокремлення вказаних підходів до розуміння розсуду є умовним, проте може сприяти коректному формулюванню змісту категорії «розсуд».

3. Судовий розсуд - обов'язковий інструмент реалізації ефективного правозастосування суду. Закономірним є той факт, що законодавець жодної демократичної держави не має можливості нормативно врегулювати у всіх деталях кожну ситуацію, що може виникнути у суспільстві. Тому всі питання, винесені за межі нормативно-правового регулювання (або мають поверхневе регулювання), проте існують у рамках права, залишаються на розсуд органів судової влади. Такий підхід, безперечно, є демократичним та оптимальним у вирішенні багатьох питань. Існування судового розсуду обумовлено об'єктивними (неможливість чітко врегулювати всі можливі життєві ситуації; динамічність суспільних відносин; потреба оперативного вирішення справи та ін.) i суб'єктивними (недосконалість чинного законодавства, прогалини у праві тощо) чинниками.

4. Судова дискреція - це правозастосовна діяльність суду, яка полягає у нормативно регламентованій можливості суддів діяти за особистими переконаннями та відповідно до міжнародних стандартів, національного законодавства, а також норм моралі під час вирішення правових конфліктів між суб'єктами права 3 метою прийняття мотивованого, законного та обгрунтованого рішення. Судовий розсуд вимагає наявності у суддів таких навичок, як розуміння наслідків від прийнятого рішення для суб'єктів права, моральної відповідальності, справедливості тощо. Іншими словами, володіти тими навичками, які фактично майже неможливо перевірити, перш ніж прийняти суддю на посаду. 


\section{Теорія, історія держави і права, конституційне право}

\section{Аітература}

1. Словник української мови: в 11 тт. / за ред. І. К. Білодіда. Київ: Наукова думка, 1970-1980. ULR: http://ukrlit.org/slovnyk/ slovnyk_ukrainskoi_movy_v_11_tomakh

2. Фразеологічний словник української мови. ULR: http://slovopedia.org. ua/49/53408/361098.html

3. Барабаш Ю. Г. Дискреційні повноваження вищих органів влади: правова природа та умови ефективного застосування. Університетсъкі наукові записки. 2007.№ 4. С. 49-54.

4. Юридична енциклопедія: в 6-ти томах / редкол.: Ю. С. Шемшученко (гол.) та ін. Київ: Укр. енцикл. ім. М. П. Бажана, 1999. Том 2: Д-Й. 744 с.

5. Дискреция / Исторический словарь галлицизмов русского язика. ULR: https:// gallicismes.academic.ru/13888/дискреция

6. Дискреція / ULR: https:// uk.wikipedia.org/wiki/Дискреція

7. Ханова Н. О. Дискреційні повноваження контролюючих органів у сфері оподаткування в Україні: дис. ... канд. юрид. наук: 12.00.07. Дніпро, 2019. 198 с.

8. Кораблина О. В. Усмотрение в правоприменительной деятельности (общетеоретический и нравственный аспекты): автореф. дис. ... канд. юрид. наук: 12.00.01. Саратов, 2009. 23 с.

9. Коренев А. П. Нормы административного права и их применение. Москва: Юрид. лит., 1978. 144 с.

10. Krauthausen R. Ermessen und unbestimmter Rechtbegriff. 1955. 287 p.

11. Барак А. Судейское усмотрение: монография. Москва: Норма, 1999. 376 с.

12. Davis K. Diskretionary Justice: Preliminary Inquiry. Baton Rouge: Louisiana State University Press, 1969. P. 164-173.

13. Тихомиров Ю. А. Административное усмотрение и право. Журнал российского права. 2000. № 4. С. 72-76.

14. Мартьянова Т. С. Розсуд суб'єктів правозастосовної діяльності: автореф. дис. ... канд. юрид. наук: 12.00.01. Аьвів, 2013. 17 c.

15. Папкова О. А. Усмотрение суда: монография. Москва: Статут, 2005. 413 с.
16. Поляков I. I. Розсуд у праві: поняття, ознаки і види. Актуальні проблеми політики. 2009. Вип. 38. С. 233-239.

17. Абушенко Д. Б. Судебное усмотрение в гражданском процессе: дис. ... канд. юрид. наук: 12.00.03. Екатеринбург, 1998. $164 \mathrm{c}$.

18. Стёпин А. Б. Судебное усмотрение в частном праве: вопросы теории и практики: дис. ... канд. юрид. наук: 12.00.01. Волгоград, 2002. 211 с.

19. Берг $\Lambda$. Н. Судебное усмотрение и его пределы: общетеоретический аспект: дис. ... канд. юрид. наук: 12.00.01. Екатеринбург, 2008. 202 с.

20. Боннер А. Т. Применение нормативных актов в гражданском процессе. Москва: Юридическая литература, 1980. 142 c.

21. Марков П. В. Правовая природа и условия осуществления судебного усмотрения: дис. ... канд. юрид. наук: 12.00.01.Москва, 2012. 180 с.

22. Юридична енциклопедія: в 6-ти томах / редкол.: Ю. С. Шемшученко (гол.) та ін. Київ: Укр. енцикл. ім. М. П. Бажана, 1998. Том 5: П-С. 736 с.

23. Резанов С. А. Класифікація адміністративного розсуду: поняття та його види. Митна справа. 2015. № 5 (101), ч. 2. С. 181-184.

24. Recommendation № $\quad \mathrm{R} \quad(80) 2$ Concerning the Exercise of Discretionary Powers by Administrative Authorities 11.03.1980. Council of Europe. URL: https:// rm.coe.int/16804f22ae

25. Морозов E. Дискреційні повноваження влади як підстава для «законної відмови». ULR: https://yvu.com.ua/dyskretsijnipovnovazhennya-vlady-yak-pidstava-dlyazakonnoyi-vidmovy/

26. Про затвердження Методології проведення антикорупційної експертизи: Наказ Міністерство юстиції України від 24 квітня 2017 № 1395/5. ULR: https:// zakon.rada.gov.ua/laws/show/v1395323-17/ card6\#Public

27. Самбор М. А. Дискреційні повноваження щодо складення протоколів про адміністративні правопорушення. Науков 


АНОТАЦІЯ
у статті розглянуто проблематику судо-
вої дискреиї (розсуду) як елемента правозас-
тосування суду з позииій науки теоріӥ держави
і права. Виокремлено наукові підходи до розу-
міння терміна «розсуду органів публічної вла-
ди». Запропоновано авторсвке формулювання
терміна «судова дискреиія».
Ключові слова: дискреиія, судовий розсуд,
дискреиійні повноваження, правова держава,
органи судової влади, громадянсъке суспіль-
ство.

записки Інституту законодавства Верховноі Ради Украӥни. 2018. № 5. С. 31-39.

28. Старик А. М. Дискреційна влада в сучасному світі. Часопис Київського університету права. 2010. № 2. С. 108-113.

29. Дискреційні повноваження органу державної влади. URL: https://protocol. ua/ua/diskretsiyni_povnovagennya_organu_ dergavnoi_vladi/

30. Ямковий В. І. Належне застосування суддівського розсуду в цивільних справах як одна з умов відновлення довіри до судової влади в Україні. Науковий вісник Херсонсъкого державного університету. Серія: Юридичні науки. 2015. Вип. 3 (1). С. 169-172.

31. Постанова Колегії суддів Другої судової палати Касаційного кримінального суду Верховного Суду у складі 01 лютого 2018 року № 634/609/15-к. URL: http://www. reyestr.court.gov.ua/Review/72009792
The article deals with the issues of judicial discretion as an element of law enforcement in the court from the standpoint of the theory of state and law.

It is emphasized that the increase of the efficiency and role of judicial authorities in the proper functioning of society as a whole and its separate subjects, in particular, is directly interrelated with the quality of court decisions. The impossibility, and the main inappropriateness, of all-purpose prescription in the normative and legal acts of the behavior of subjects of law in different life situations is solved by making decisions at their discretion by various subjects of power, in particular by the judiciary corps, thereby implementing the discretionary powers provided for by law.

It is accentuated that the emergence of judicial discretion as a legal phenomenon dates back to the ancient times and is proportionally related to the emergence of the institute of justice. Despite the normative attachment and use of the term "judicial discretion" in the literature for quite a long time, its repeated mentioning and interpretation in decisions of various instances of the judiciary, the content of this term remains controversial.

It is noted that the analysis of encyclopedias and scientific sources regarding the relation between the categories of discretion and judgement of public authorities indicates their identity. The study of foreign and domestic scientific doctrine regarding the understanding of the discretion of public authorities has given rise to the following approaches in this direction: 1) discretion as a measure of freedom; 2) discretion as a separate activity; 3) discretion as a way of deciding without regard to the will of other subjects; 4) discretion as a power provided by law, etc.

It is emphasized that judicial discretion is a mandatory instrument for the effective law enforcement of the court. The existence of judicial discretion is due to objective (impossibility to clearly resolve all possible life situations, the dynamism of social relations, the need for operative solution of the case, etc.) and subjective (imperfection of the current legislation, gaps in law, etc.) factors.

Key words: discretion, court discretion, discretionary powers, law state, judicial authorities, civil society. 